\title{
Isolation and identification of Circovirus in pigeon
}

\author{
S.Y. Al-Baroodi $\odot$ and M.Y. Al-Attar ${ }^{\circledR}$ \\ Department of Microbiology, College of Veterinary Medicine, University of Mosul, Mosul, Iraq
}

\begin{tabular}{l} 
Article information \\
\hline Article history: \\
Received February 21,2020 \\
Accepted March 27, 2020 \\
Available online November 5, 2020 \\
\hline Keywords: \\
Circovirus \\
Pigeon \\
Virus isolation \\
Polymerase chain reaction \\
Mosul \\
\hline Correspondence: \\
S.Y. Al-Baroodi \\
safwanalbaroodi@ yahoo.com
\end{tabular}

\begin{abstract}
The purpose of this study is first trial to detect of pigeon circovirus, so 1sr group include 100 cloacal swabs were collected 55 healthy and 45 ill pigeons, 36 yearlings and 64 adults, the 2nd group included organs was liver, spleen, bursa of Fabricius from 41 young pigeons 10-30 days old and bursa of Fabricius, liver, spleen from 28 dead in shell pigeon embryo in the 3rd group. DNA extracted from this samples and detection of virus DNA was attempt using polymerase chain reaction, after DNA amplification, the final products of the amplicon with $331 \mathrm{bp}$ was cleared by using electrophoresis using agarose gel at concentration $2 \%$. Results of viral DNA amplification were positive, which revealed as band in $331 \mathrm{bp}$ the results showed that ill yearling pigeons recording high infectivity rate $66.7 \%$ compare with healthy yearling pigeons and adult once, the bursa of Fabricius samples of dead yearling pigeons recorded high prevalence $36.58 \%$ when compare with liver and spleen samples, DNA of pigeon circovirus high detected $60.71 \%$ in bursa of Fabricius of dead in shell pigeon embryo.in conclusion pigeon circovirus affected the racing pigeon in Mosul, Iraq.
\end{abstract}

DOI: 10.33899/ijvs.2020.126706.1364, (02021, College of Veterinary Medicine, University of Mosul.

This is an open access article under the CC BY 4.0 license (http://creativecommons.org/licenses/by/4.0/).

\section{Introduction}

Pigeon circovirus belongs to the genus Circovirus, family Circoviridae. It classified with other viruses in same genus including duck circovirus, porcine circovirus 1 and 2, canary circovirus, goose circovirus. The virus is belonging to psittacine beak and feather disease virus $(1,2)$. Pigeon circovirus is small single stranded DNA virus, it is 15-20 $\mathrm{nm}$ in diameter, non-enveloped (3). The virus has wide range hosts including several domestic and wild birds causing variety of clinical signs including loss of weight, loss of feathers, dullness, and the crop impacted with yellowish fluid, poor racing, poor growth, abnormal in respiration, severe diarrhea, immunosuppression which cause activation of other secondary infection and the mortality rate reach up to $20 \%$ (4). These clinical signs are merged in a term Young Pigeon Sickness (YPS) $(5,6)$. The virus transmitted horizontally through the ingestion of the pigeon contaminated food and water with faeces of infected pigeon (7) or via crop milk from adults to young pigeons during $1^{\text {st }}$ days after hatch (8), also through the inhalation as well as the virus can be transmitted vertically to embryo (9). Pigeon circovirus is worldwide distribution due to difficult biosecurity program in racing pigeon. There are no vaccines against pigeon circovirus but recently the researchers can be developed subunit vaccine (capsid) but this vaccine is under experimental condition only (10).

The diagnosis of pigeon circovirus is difficult so that many researchers used histopathological and electron microscopy, some authors used virus isolation in cell culture line but this method is limited and failed (11). Because of these reasons and limitation of propagation of virus in cell culture and lack of specific pigeon circovirus immunoglobulin, researchers approach to advanced technique to diagnosis this virus like dot blot hybridization and a number of PCR tests (12). Because no reports describing the detection of pigeon circovirus in Iraq, this study was done to detect circovirus in pigeon using PCR in Mosul, Iraq. 


\section{Materials and methods}

\section{Birds}

Birds including racing pigeons Columba livia, some of these birds looks healthy and the others suffering from diarrhea, poor racing exercises, retardation of growth, loss of feathers, were used in this study.

\section{Samples collection}

Group 1, cloacal swabs were taken from 55 healthy and 45 ill pigeons 36 yearlings and 64 adults. Group 2, organs samples are liver, spleen, bursa of Fabricius were obtained from 41 dead young pigeons 10-30 days of age. Group 3, organs samples are liver, spleen, bursa of Fabricius were taken from 28 dead in shell pigeons embryos, all samples were stored in $-20^{\circ} \mathrm{C}$ until laboratories processing.

\section{DNA extraction}

Viral DNA extraction of cloacal swabs and tissue from dead pigeon and dead embryos was attempt using QIAamp ${ }^{\circledR}$ DNA Mini Kit (catalog no 51306), Polymerase Chain Reaction (PCR), PCR assays attempted according to (13) the primers forward 5'GCATAAGGTGCCCGTGAAAGG'3 and reverse primers 5'ATTCGCGGTCGCTCCGCT'3 the primers added $50 \mathrm{uM}$ in $50 \mathrm{ul}$ of mixture of reaction which contain 25 ul of master mix (Qiagen), 10 ul of Q solution 5 ul of each primers and DNA templates, then the amplification of reactions was performed using thermocycle according the following program, initial denaturation $\left(2 \mathrm{~min}\right.$ at $\left.94^{\circ} \mathrm{C}\right)$ was followed by 45 cycles of the following steps $45 \mathrm{sec}$ at $94.0^{\circ} \mathrm{C}, 60 \mathrm{sec}$ at $64.5^{\circ} \mathrm{C}, 60 \mathrm{sec}$ at $72.0^{\circ} \mathrm{C}$ and a final elongation step for $7 \mathrm{~min}$ at $72.0^{\circ} \mathrm{C}$, the final product of the amplicon with 331 bp was cleared by using electrophoresis using agarose gel at concentration $2 \%$.

\section{Results}

The results of viral DNA amplification were positive, which revealed as band in $331 \mathrm{bp}$ (Figure1). The results of clinical finding revealed retardation of growth, loss of feathers, some embryo of pigeons were dead in shell in different ages (Figures 2 and 3 ).

The group 1 cloacal swabs of ill and healthy pigeons showed high infectivity rate in yearling bird when compare with adult once. As well as the ill yearling pigeons recording high infectivity rate when compared with healthy yearling pigeons (Table 1).

In group 2 organs of dead younger birds showed high rate of viral infection in bursa of Fabricius samples when compare with liver and spleen samples (Table 2).

In group 3, the results of detection of viral DNA of pigeon circovirus in 28 dead in shell pigeon's embryos showed the high rate of viral DNA in bursa of Fabricius when compare with liver and spleen (Table 3 ).

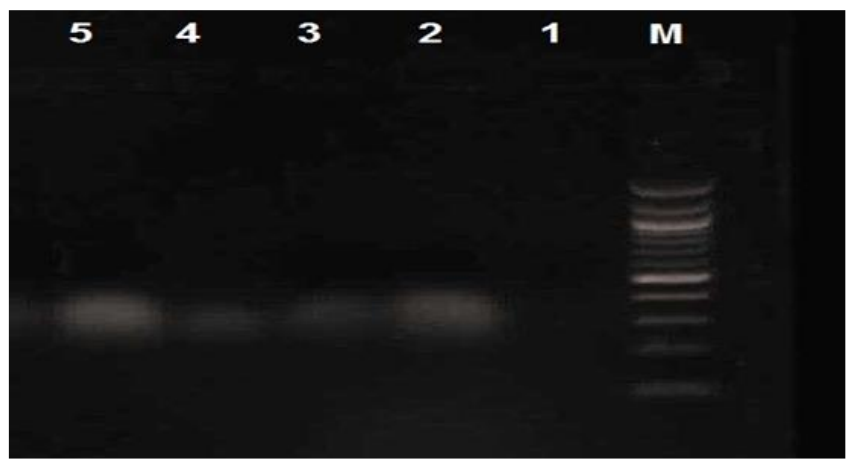

Figure 1: Results of DNA amplification of cloacal swabs, $\mathrm{M}=$ Marker, $1=$ Negative result, $2-5=$ positive results.

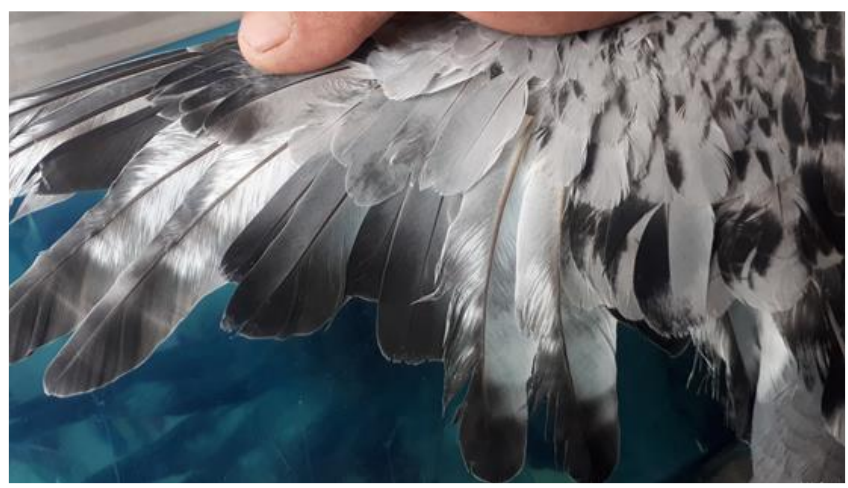

Figure 2: Male racing pigeon 8 months of age suffer from retardation of growth and loss of feathers.

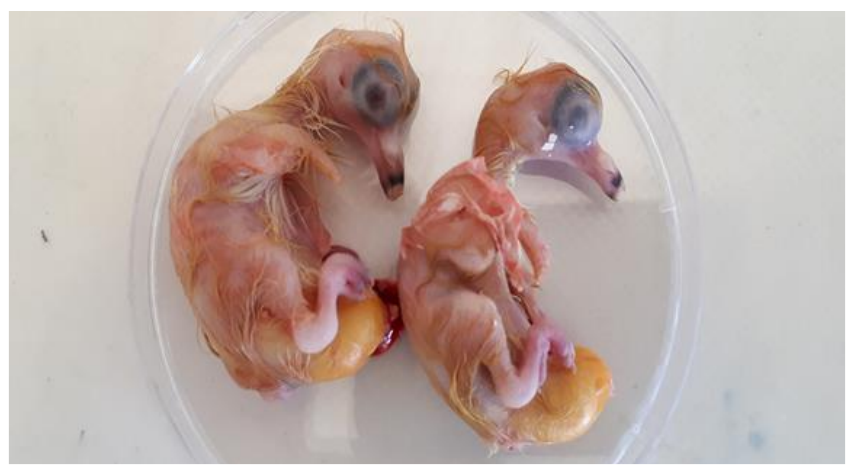

Figure 3: Dead pigeon embryo 13-day post incubation and positive to pigeon circovirus.

Table 1: Infectivity rate of pigeon circo virus in yearling and adult pigeons compare with healthy status using PCR

\begin{tabular}{lccc}
\hline Age & Health & N samples & N positive $(\%)$ \\
\hline Adult & Healthy & 40 & $3(7.5 \%)$ \\
& Sick & 24 & $7(29.2 \%)$ \\
Yearling & Healthy & 15 & $3(20 \%)$ \\
& Sick & 21 & $14(66.7 \%)$ \\
\hline
\end{tabular}


Table 2: Infectivity rate of pigeon circovirus in organs of dead yearling pigeon using PCR

\begin{tabular}{lcc}
\hline Organ & N samples & N positive (\%) \\
\hline Liver & 41 & $12(29.26 \%)$ \\
Spleen & 41 & $12(29.26 \%)$ \\
bursa of Fabricius & 41 & $15(36.58 \%)$ \\
\hline
\end{tabular}

Table 3: Detection of pigeon circovirus DNA in dead in shell pigeon embryos

\begin{tabular}{lll}
\hline Organ & N samples & N positive (\%) \\
\hline Liver & 28 & $9(32.41 \%)$ \\
Spleen & 28 & $9(32.14 \%)$ \\
bursa of Fabricius & 28 & $17(60.71 \%)$ \\
\hline
\end{tabular}

\section{Discussion}

Pigeon circo virus is one of the most dangerous viral pathogens to racing pigeon, the clinical signs manifested by death of embryo, retardations of growth, diarrhea and feather loss (3). Our study revealed the effects of pigeon circo virus on breeding of racing pigeons at different area of Mosul city, the 1st group of pigeons showing the presence of circovirus DNA in cloacal swabs in healthy, ill pigeons, adult, and yearling one. Other researchers approved the presence of viral DNA in cloacal swabs with high prevalence without the study of the relationship between age and infection rate (14), the presence of viral DNA in cloacal swabs was proved the role of contaminated food and water with fecal material to horizontal transmission of the virus. The high infective rate in yearling (younger) pigeon was explained by (3) which said the role of stress factors to spreading of circo virus like weaning, overcrowding and vaccination.

The high prevalence of viral DNA in bursa of fabrecia of dead yearling pigeon, those result was interpreting by (7) which suggest of primary burso-tropism of pigeon circovirus, followed by secondary systemic spread from the bursa of Fabricius, particularly to non-bursal lymphoid organs. The differences between the infective rate of viral DNA of organs in the same birds was represented to the stage of pathogenesis of virus in pigeons. Other researchers (15) indicate that the circovirus infections are highly prevalent in young pigeons, it is very unlikely that all of these older birds, which were derived from varied sources, were experiencing infections resulting from recent exposure to PICV, but rather that the virus DNA had persisted from infections that occurred when the pigeons were young

The result of detection of circovirus DNA in dead shell embryo revealed high infective rate in lymphoid organ. Some researchers study this cases in pigeon embryo (12) which interpret that the detection of PICV in embryonic tissue suggested vertical transmission of the agent and virus persistence in the adult pigeon. Other study (16) recorded high prevalence of pigeon circovirus in pigeon embryo and adult pigeon when compare with younger once, thus study explain the role of vertical transmission of circo virus between adult and its embryo and interpret the low prevalence of infection in younger pigeon to breeding program which quickly excludes the ill younger pigeons and this due to decrease the infective sample in thus study.

In this study the importance of PCR technique to detect the pigeon circo virus DNA that there is no specific antisera is available against pigeon circovirus as well as no commercial ELISA kits was available, many studies can be used this technique because PCR is a quick and confirmatory test when compare with other diagnostic techniques (17).

This study conducted that pigeon circovirus is spreading in pigeon lofts in Mosul city and it is affecting the pigeon breeding. The reasons of spreading of this virus may be due to several factors including no pigeon circovirus vaccines is available, no vaccines programs against pigeon herpes virus, pigeon adeno virus and other viruses which increase the manifestation of this disease (18), the pigeon circovirus usually appear as outbreaks in racing period due to contact of pigeon with others pigeon in different cities in a path of racing lines, the last reason that the importation of the pigeons from foreign countries which considered as positive to pigeon circovirus without any quarantine measures (Field observer to researchers).

\section{Conclusions}

Pigeon Circovirus was distributed in pigeon in Mosul city and transmitted horizontally and vertically.

\section{Acknowledgment}

The authors wish to thank College of Veterinary Medicine, University of Mosul for financially supporting this work, laboratory of veterinary teaching hospital, for their support and the animal's owners for their cooperation

\section{Conflict of interest}

Authors declare no conflict of interests of the manuscript.

\section{References}

1. Taras L, Kubiaek $\mathrm{O}$, Juranov $\mathrm{R}$ and Jurajda, V. The First Demonstration of Pigeon Circovirus Infection in the Czech Republic. Acta Vet Brno. 2003;72: 577-582. DOI: 10.2754/avb200372040577.

2. Rahaus M, Desloges N, Probst S, Loebbert B, Lantermann W, Wolff $\mathrm{MH}$. Detection of beak and feather disease virus DNA in embryonated eggs of Psittacine birds. Vet Med. 2008;53(1):53-58. DOI: 10.17221/1932-VETMED

3. Tomasz S, Daria D, Bartłomiej T, Marcin S, Joanna K, and Andrzej K Immunogenicity of pigeon circovirus recombinant capsid protein in 
pigeons.Viruses. 2018;596(10):1-12. www.ncbi.nlm.nih.gov/pubmed/ 30384424.

4. Duchatel J, Jauniaux T, Smyth J, Habsch I, de Bournonville M, Losson B, Todd D. Effect of a commercial paratyphus vaccine on the development of pigeon circovirus infection in young pigeons (Columba livia domestica). J Avian Med Surg. 2010;24(2):107-114. DOI: $10.2307 / 40793251$

5. Duchatel J.P, Todd D, Smyth J, Costes B, Januniaux T, Farnir F, Losson B, Vanderplasschen A. Pigeon circovirus expression of the capsid protein gene, specific antibody and viral load measured by Real Time Polymerase Chain Reaction. Israel J Vet Sci. 2011;66(1):26-31. www.reserchgate.net/publication/287765717.

6. Duchatel J, Pioter S. Young pigeon disease syndrome. Medycyna Wet. 2011;67(5):291-294. DOI: 10.1080/03079450500267825

7. Jerome A, Frederique N, Caroline G, Nadia A. Bernard F, Catherine G, Lydie G, Philippe R, Bernard L and Monique W. Pigeon circovirus infection pathological observations and suggested pathogenesis. Avi Pathol. 2001;30:149-158. DOI: 10.1080/03079450124811

8. Volker S, Julian S, Caroline L, Reimar J, Barbara B, Hermann M, Maria J. Experimental infection of domestic pigeon with pigeon circo virus. Avi $\quad$ Dis. 2008;52(3):380-386. https://www.jstor.org/stable/27565760

9. Leslie W, Kenneth S, Frank N, Craigmyle R, Ann M, Mark A, Barbara M, Daft J, Raymond P, Robert N. A retrospective study of circovirus infection in pigeons: Nine cases (1986-1993). J Vet Diagn Invest. 1994;6:156-164. DOI: 10.1177/104063879400600205

10. Attila CS, Ma O, Klata T, Zso FW, Tama T. Genetic diversity of pigeon circovirus in Hungary. Virus Genes. 2012;44:75-79. doi:10.1007/s11262-011-0669-6

11. Iris D, Tim F, Stefan H, Thomas W, Annette M, Rüdiger K and Christian G. Cloning and expression of a truncated pigeon circovirus capsid suitable for antibody detection in infected pigeons. Avi Pathol. 2009;38(2):135-141. doi: 10.1080/03079450902737797

12. Dirk S, Kim H, Kerstin A, Joaquim S, Mariano D, Cornelia S, Annette M. A diagnostic study on columbid circovirus infection. Avi Pathol. 2001;30:605-611. DOI:10.1080/03079450120092099.

13. Duchatel J, Todd D, Smyth J, Bustin J, Vindevogel H. Observations on detection, excretion and transmission of pigeon circovirus in adult, young and embryonic pigeons. Avi Pathol. 2006;35(1), 30-34. doi.org/10.1080/03079450500465692

14. Todd D, Duchatel J, Bustin J, Scullion F, Scullion M, Scott A, Curry N, Ball W, Smyth J. Detection of pigeon circovirus in cloacal swabs: Implications for diagnosis epidemiology and control. Vet Rec. 2006;15(2):314-317. DOI:10.1136/vr.159.10.314

15. Tomasz S, Andrzej K. The epidemiology, molecular characterization and clinical pathology of circovirus infections in pigeons. Vet Quart. 2017;37(1):166-174. Doi: 10.1080/01652176.2017.1325972
16. Duchatel J, Todd D, Curry A, Smyth J, Bustin J, Vindevogel H. New data on the transmission of pigeon circovirus. Vet Rec. 2005;157:413415. DOI:10.1136/vr.157.14.413

17. Parimal R, Dhillon A, Lloyd L, Shivaprasad HL. Detection of pigeon circovirus by polymerase chain reaction. Avi Dis. 2003;47:218-222. DOI: 10.1637/0005-2086(2003)047[0218:DOPCBP]2.0.CO;2

18. Alesksandraledwon T, Declano D, Sean M, Chris L, Tadeusz W, Joergkinne C, Urich W. Prevalence of circovirus and adenovirus in pigeons in Dubai. Medycyna Wet. 2011;67(11):752-756. www.resrearch gate.net

$$
\begin{aligned}
& \text { عزل وتحديد فايروس Circo في الحمام } \\
& \text { صفوان يوسف البارودي و مزاحم ياسين العطار } \\
& \text { فرع الأحياء المجهرية، كلية الطب البيطري، جامعة الموصل، البل، } \\
& \text { الموصل، العراق الأياء } \\
& \text { الخلاصة }
\end{aligned}
$$

إن الغرض من هذه الدراسة هو أول الكثف عن فيروس circo

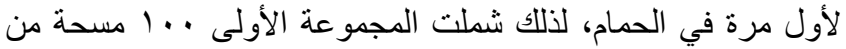

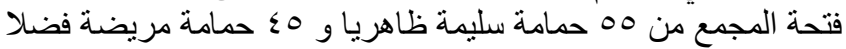

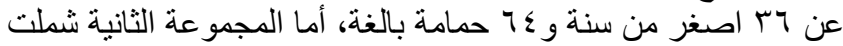

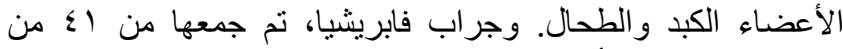

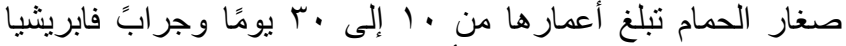

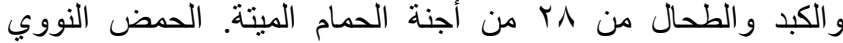
المستخلص من هذه العينات نم الكثف عنه من خلان تلف تفاعل سلسلة

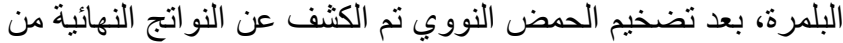
الأمبليكون بحجم ناتج نهائي ابراب باستخدام الترحيل الكهربائي في جل

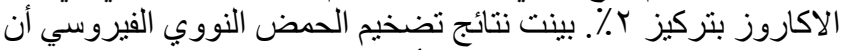

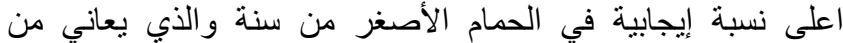

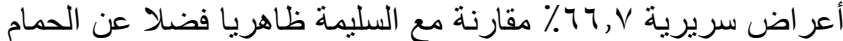

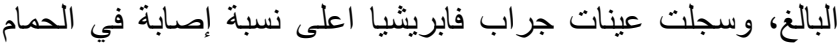

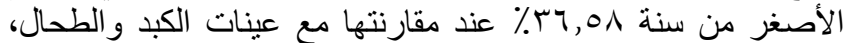

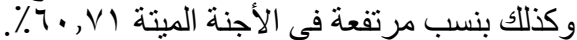

